\title{
Root foraging and yield components underlying limited effects of Partial Root-zone Drying on oilseed rape, a crop with an indeterminate growth habit
}

\author{
Jinfeng Wang • Hans de Kroon • Ling Wang • Hannie de Caluwe • \\ Gerard M. Bögemann • Gerard M. van der Weerden • Shaozhong Kang • \\ Antoine J. M. Smits
}

Received: 20 October 2008 /Accepted: 3 February 2009/Published online: 13 March 2009

(C) The Author(s) 2009. This article is published with open access at Springerlink.com

\begin{abstract}
We report on two experiments with oilseed rape (Brassica napus L.) to test if partial root-zone drying techniques improve yield in a crop in which vegetative and reproductive growth overlap (indeterminate growth habit), and to investigate what plant morphological responses contribute to the yield that is realized. Deficit irrigation resulted in smaller plants with smaller yields but larger seeds compared to treatments with shallow groundwater (first experiment) and with fully watered conditions (second experiment). Different partial root-zone drying treatments (water supply patterns) under deficit irrigation, however, had little effect on plant growth and yield components (number of branches, branch lengths, number of pods, etc.). Our results suggest that partial
\end{abstract}

Responsible Editor: Tibor Kalapos.

J. Wang $\cdot$ H. de Kroon $(\bowtie) \cdot$ L. Wang $\cdot$ H. de Caluwe

G. M. Bögemann

Department of Experimental Plant Ecology,

Radboud University Nijmegen,

P.O. Box 9010, Nijmegen, The Netherlands

e-mail: H.deKroon@science.ru.nl

J. Wang $\cdot$ S. Kang

Key Lab of Agricultural Soil and Water Engineering in Arid and Semiarid Areas, Ministry of Education,

Northwest Agriculture and Forestry University,

Yangling, Shaanxi 712100, People's Republic of China

L. Wang

College of Water Resources and Hydrology,

Hohai University,

Nanjing 210098, People's Republic of China root-zone drying doesn't work well with oilseed rape. Detailed measurements of soil water contents and root distribution indicate that roots were extremely plastic, effectively foraging for water, and these root responses may have overwhelmed physiological effects of partial root drying on the shoot. Furthermore, in crops with indeterminate growth with a short vegetative growth phase, partial root-zone drying may be ineffective in enhancing the major yield components. Further reasons for the lack of success are discussed.

Keywords Partial root-zone drying - Oilseed rape · Shallow groundwater - Soil water content . Root foraging $\cdot$ Seed yield

G. M. van der Weerden

Botanical and Experimental Garden, Radboud University Nijmegen, P.O. Box 9010, Nijmegen, The Netherlands

S. Kang

Center for Agricultural Water Research in China,

China Agricultural University,

Beijing 100083, People's Republic of China

A. J. M. Smits

Centre for Sustainable Management of Resources, Radboud University Nijmegen,

P.O. Box 9010, Nijmegen, The Netherlands 


\section{Introduction}

Because water supplies are limited worldwide, enhancing water use efficiency both under rain fed and irrigated agriculture is a high priority for agricultural improvement in developing countries (Buttar et al. 2006). Specific irrigation technologies have been tested to develop precision agriculture (Kang et al. 2000; Panda et al. 2003; Wakrim et al. 2005), including Alternate Partial Root-zone Drying irrigation (APRD) as a new water-saving irrigation technique (Kang and Zhang 2004; Centritto et al. 2005; Liu et al. 2006). Previous studies on APRD showed that it provides a means of reducing water consumption while minimizing adverse effects on yield (Sepaskhah et al. 1997; Kang et al. 2000; Kirda et al. 2004). In APRD only part of the root system is irrigated, and dry and irrigated parts of roots are alternated, resulting in an effective transport of drought signals from the roots to the shoot and higher water use efficiency (Davies et al. 2000; Kang et al. 2002). APRD has been shown to be improving yield in crops (Kang et al. 2001, 2002; Zegbe-Domínguez et al. 2003-hot pepper, maize, tomato) and fruit trees (Cifre et al. 2005; Leib et al. 2006-grapevine, apple).

Oilseed rape (Brassica napus L.) is the most important oil plant in China, occupying about 6.7 million ha, producing 10 million tons seed and 6 million tons meal. It can be grown under a wide variety of soil, water and climatic conditions (Al-Jaloud et al. 1996). Many aspects of plant physiological and morphological characteristics and productivity of oilseed rape have been studied under different irrigation, fertilizer and field management (Mandal et al. 2006; Rathke and Diepenbrock, 2006; Buttar et al. 2006), including water stress (Jensen et al. 1996; Mogensen et al. 1997; Maisiri et al. 2005). Oilseed rape is known to be very flexible in its response to different growth conditions (Zhang et al. 2004; Black et al. 2007). However, comparatively little is known of the effects of APRD on rape root growth and changes in plant morphology contributing to differences in yield.

Our previous greenhouse studies revealed that oilseed rape roots were able to forage for fixed water patches by selective root placement (Wang et al. 2005, 2007). Fixed watering and alternate watering generally outperformed uniform watering in terms of vegetative growth, as a result of effective root foraging and enhanced water use efficiency, respectively. Here we examine root spatial distributions and yield response under APRD in the longer term under simulated field conditions. In addition, we test if root responses to water patterns were affected by shallow groundwater, as it may occur under crop field conditions. Groundwater may be accessible by the deep roots, but we don't know how effective the roots are in alleviating water shortage, and whether they alter the effects of different water patterns. Soil water content in shallow and deeper layers were monitored continuously and root vertical and horizontal distributions were investigated to examine how effective roots foraged for shallow water patches as well as for deeper groundwater.

As plants did not flower in our previous experiments (Wang et al. 2005, 2007) we do not know whether seed yield is affected similarly as vegetative growth. In a crop as oilseed rape with an indeterminate growth habit in which the reproductive growth phase largely overlaps with the vegetative growth phase, these phases may respond differently to environmental conditions. There are indeed indications that responses of vegetative biomass and grain yield are not always the same (Kang et al. 2000), but the reasons for this, for example, due to changes in plant morphology, have not been studied. Hence, the present study was taken up to determine the effects of irrigation pattern on different yield components including plant morphological characteristics, biomass, flowering and yield. As changes in morphology were modest in our first experiment with shallow groundwater, and because we had indications that differences in watering between treatments became apparent fairly late during plant development, we repeated the experiment in which plants were subjected to differences in watering amount immediately from the start of the experiment.

\section{Materials and methods}

Similar oilseed rape Brassica napus L.var. Huyou 15 was used in this study as in our previous studies (Wang et al. 2005, 2007). This variety of oilseed rape is developed in the middle and lower reaches of Changjiang River in monsoon climate (Sun et al., 2002; Zhang and Yu 2003), where the crop is grown in the dry period of winter and spring. The experimental plants were grown under the mild winter conditions of 
the Atlantic climate in the Netherlands, but under the rain shelter of the Nijmegen Phytotron allowing us to control the watering regimes.

\section{Experiment 1}

Experiment 1 was conducted in the Phytotron of Radboud University Nijmegen, a new experimental facility to study belowground processes at mesocosm scale under near-ambient conditions (www.science.ru. $\mathrm{nl} /$ phytotron). It consists of two rows of large polyester containers covered by a transparent rain shelter and open at all sides except for wire-netting. Permanent monitoring by weather stations showed that temperature and irradiance indeed closely followed ambient fluctuations. For this experiment, eight containers were used, each of them partitioned into three compartments of $50 \mathrm{~cm} \times 50 \mathrm{~cm} \times 70 \mathrm{~cm}$ (width $\times$ length $\times$ depth).

The bottom of each compartment was filled with 5 $\mathrm{cm}$ gravel, covered with seed cloth. The compartments were subsequently filled with garden sand, containing $13.3 \mathrm{~g} \mathrm{~kg}^{-1}$ organic matter, and 0.8 and
$0.57 \mathrm{mg} \mathrm{kg}$ total $\mathrm{N}$ and $\mathrm{P}$, respectively. $48.6 \mathrm{~g}$ slowly released fertilizer ( 9 months) Osmocote exact (9-18-12-2 MgO-Te, the Scotts Miracle-Gro Company, USA) was applied homogeneously and mixed with the top soil (upper $20 \mathrm{~cm}$ ) of all the compartments prior to transplanting. Bulk density of the soil was about $1.2 \mathrm{~kg} \mathrm{~L}^{-1}$. Field water capacity, the water content of the soil where all free water has been drained from the soil through gravity, was determined at $28.1 \%(\mathrm{v} / \mathrm{v})$, compared to about $45 \%(\mathrm{v} / \mathrm{v})$ water content for completely saturated soil.

Oilseed rape was sown in germinating boxes in the greenhouse at the end of October and planted at the 4-leaf stage in the containers on 1st of November 2006. In each compartment, 4 plants were planted in two lines watered by three furrows (front, middle and back furrow). The spacing was $25 \mathrm{~cm}$ between rows and $25 \mathrm{~cm}$ between plants in each row (Fig. 1).

A constant shallow groundwater level was created by filling water via a $1 \mathrm{~cm}$ diameter open water gauge to the bottom of the compartment. It was replenished during each watering until a $5 \mathrm{~cm}$ water table above
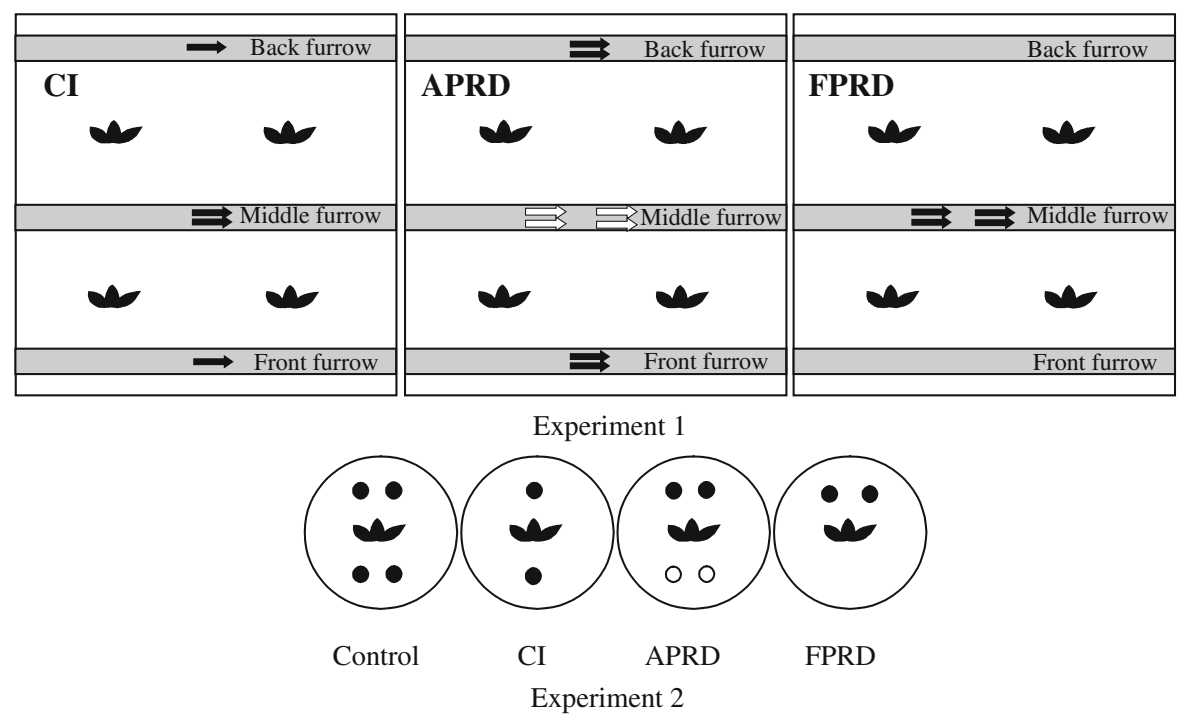

Fig. 1 Experiment 1: Layout of the experimental compartment $(50 \times 50 \mathrm{~cm})$ with 4 plants and 3 watering furrows, with arrows indicating the amount of water given. Under Conventional Irrigation (CI-black arrows) the middle furrow was supplied with twice the amount of water than each of the side furrows. For Alternate Partial Root-zone Drying Irrigation (APRD), white and black arrows indicate alternating watering regimes in subsequent weeks, i.e. all of the water was supplied to the middle furrow in one week, and half of the amount of water to each of the front and back furrows in the following weeks. Under Fixed Partial Root-zone Drying Irrigation (FPRD), water was only supplied to the middle furrow. The total amount of water supplied was exactly the same for all three water patterns. Experiment 2: pot layout with black circles as drippers. In the Control treatment $(100 \%)$, plants were watered on both sides of the pot, soil water content was maintained around field capacity. Conventional irrigation (CI-50\%), plants were watered on both sides with half of the amount of water compared to Control. Under APRD (50\%), white and black circles indicate that plants were watered alternately on both sides. In FPRD (50\%) only one side of the plants was watered, the other side was dried down 
the bottom of the container was reached. Half of the containers were assigned to the groundwater water level treatment, and half to a control treatment (drained). For both groundwater and control treatments, three watering patterns were applied to the top layer of the soil (Fig. 1): conventional irrigation (CI watering every furrow every time), Alternate Partial Root-zone Drying Irrigation (APRD, watering side furrows and middle furrow alternately) and Fixed Partial Root-zone Drying Irrigation (FPRD, watering was fixed at middle furrow every time). The factorial combination of these two factors yielded 6 treatments. Each treatment had 4 replications. Two adjacent containers ( 6 compartments) with all 6 distinct treatments $(2$ groundwater $\times 3$ water patterns) were placed together within the Phytotron as one block. Watering treatments were randomly assigned to compartments within a container.

Groundwater was setup immediately after transplantation. Water pattern treatments started in the middle of January, 2007. All water pattern treatments were given exactly the same amount of water during the whole experimental period. Watering schedule and amount were varied with seasonal change. Watering frequency changed from once a week, twice a week to three times a week. The middle furrow was supplied with twice the amount of water at each of the side furrows. In the APRD treatment watering shifted every week alternately between the middle furrow and the side furrows.

Time domain reflectometry (TDR) probes (Watersmartprobes, PRIVA, de Lier, the Netherlands) were used in this study to measure soil water content every 5 min during the experimental period automatically for one container of each treatment. Two probes were placed at $20 \mathrm{~cm}$ depth, one beneath the front furrow and one beneath middle furrow respectively, and one probe in the middle of the compartment at a depth of $50 \mathrm{~cm}$. Two more probes were placed in the top layer of soil at the side furrow and middle furrow in APRD without groundwater treatment. In addition, the soil water content of each container in the top layer $(6 \mathrm{~cm})$ was measured weekly during the end of March till the end of May with moisture meter type $\mathrm{HH} 2$, sensor Theta Probe type ML2x, (Delta-T Devices Ltd, UK).

Because of the exceptionally warm winter 2006 and spring 2007 in the Netherlands, oilseed rape started bolting already in late February, flowering in early March and fruiting at the end of March. All of the leaves were senesced at the beginning of May. Plants were harvested at the beginning of June, prior to seed shatter. All plants were harvested and morphological parameters were recorded, including height, branch length, and number of branches, pods and aborted flowers. Aboveground dry biomass was partitioned into stem and branch, seeds and pod walls, determined after constant drying at $70^{\circ} \mathrm{C}$ for at least $48 \mathrm{~h}$.

Root samples were collected after shoot harvesting. Root cores (4 $\mathrm{cm}$ in diameter) were taken in the middle of each furrow exactly in between the plants, separated in three layers (each $20 \mathrm{~cm}$ in depth). Roots were collected carefully by washing the soil samples, and clean roots were scanned (EPSON expression 10000XL, EPSON America Inc.) and root length was measured with WinRHIZO software (Regent Instrument Inc. Canada).

\section{Experiment 2}

A pot experiment was conducted at rain shelter in the Radboud University Nijmegen experimental garden using 120 pots $(28 \mathrm{~cm} \times 25 \mathrm{~cm}$, diameter $\times$ depth $)$ each holding approximately $18.53 \mathrm{~kg}$ garden sand which was the same as in experiment 1, packed to a bulk density of $1.2 \mathrm{~kg} \mathrm{~L}^{-1}$.

The oilseed rape was sown in germinating boxes in the greenhouse at the beginning of May, 2007 and planted in small pots 10 days later. Plants were given a cold treatment $\left(3-4^{\circ} \mathrm{C}\right)$ for one week at the 4-leaf stage, after which they were transplanted to pots in the rain shelter. This experiment included four treatments, a control (with soil water content maintained around field capacity) and three water pattern treatments (CI, APRD and FPRD) in which half of the amount of water of the control was supplied. There were 30 replicates per treatment in a randomized complete block design. Plants were watered by a trickle irrigation system (Fig. 1). The different water patterns were started before transplantation. The watering side of the APRD shifted weekly. The soil water content of ten of the replicates was observed for three times a week during the experiment period (from early May to early September, 2007) with moisture meter type $\mathrm{HH} 2$, as used in Experiment 1. Oilseed rape started bolting in mid-June, flowering and started losing leaves in late-June, and fruiting in early-July. Twenty blocks containing all four treatments were harvested in late August and similar aboveground measurements were taken as in Experiment 1. Root samples were collected after shoot harvesting. Root 
cores $(4 \mathrm{~cm} \times 20 \mathrm{~cm}$ in diameter $\times$ length) were taken in the middle of each half of the pot and treated as the same way as in Experiment 1.

\section{Statistical analysis}

All statistical procedures were performed using Statistic Analysis System software (SAS, Version 9.13, SAS Institute Inc., USA). Data were checked and transformed as necessary to meet the requirements of ANOVA (normal distributions, homogeneity of variance).

Experiment 1. Two-way (groundwater, water pattern) analysis of variance (ANOVA) (fixed model) with block as a covariate was conducted. For root data, 9 root samples were collected in one compartment (3 furrows $\times 3$ layers ), repeated measures analysis of variance was used to analyze these data. Results for furrows (horizontal distribution, average over all layers) and layers (vertical distribution, average over all furrows) were analyzed separately and the repeated factors were furrow and layer, respectively. In the first case, when furrow was taken as the repeated measurement factor, the average of root length density of three layers in same furrow was calculated for analysis (Furrow Model). Similarly, the average of root length density of three furrows in the same layer was computed for analysis when the repeated measurement factor was layer (Layer Model).

Experiment 2. One-way (water pattern) analysis of variance (ANOVA) (fixed model) with block as a covariate was conducted. Because two root samples were collected in each pot, repeated measurement analysis of variance was used to analyze root data.

\section{Results}

\section{Experiment 1}

\section{Soil water content (SWC)}

The dynamics of SWC in the top soil depended on the water pattern treatment, and were essentially the same under drained and groundwater conditions (Fig. 2). Even under Control (CI) irrigation, SWC fluctuated considerably and in parallel for the three furrows (Fig. 2a, d). The high constant SWC level in May was due to lower transpiration, because plants began to lose their leaves at this stage. As expected for the
Alternate treatment (APRD), the SWC of the middle furrow fluctuated alternately with the SWC of the front and back furrows (Fig. 2b, e). Fig. 2c,f show that for Fixed watering (FPRD) the soil was very dry in front and back furrow, lower than $5 \% \mathrm{v} / \mathrm{v}$, except a slight upward trend at the end of experiment in compartments with shallow groundwater. But the fluctuations of SWC of the middle furrow were the same as in the Control CI treatment.

In drained treatments without shallow groundwater, soil water content (SWC) at a depth of $50 \mathrm{~cm}$ decreased gradually from $25 \%$ (volumetric soil water content) at the start of the experiment in early November 2006 to $5-8 \%$ in mid-March 2007, remaining constant until the end of the experiment. The deeper soil became slightly drier under APRD than under CI and FPRD (Fig. 3a-c).

In treatments with shallow groundwater, soil was very wet at $50 \mathrm{~cm}$ depth and SWC depended on treatment. SWC rose sharply from $25 \%$ at the beginning of the experiment to $46 \%, 35 \%$ and $42 \%$ in CI, APRD and FPRD, respectively, in early November, and stabilized from then on. There was a little SWC drop in the CI and FPRD treatments during hot weather in mid-April which recovered rapidly until $45 \%$ and $40 \%$, respectively (Fig. 3d-e). But SWC in APRD fell to $23 \%$ at the middle of April and stayed relatively low until the end of experiment (Fig. 3f).

Two TDR probes, located at a depth of $20 \mathrm{~cm}$ under the front furrow and middle furrow respectively, showed intermediate SWC dynamics compared to the top soil and deep soil layers, as described above. In general, for drained treatments, there was not a great difference between the SWC of front and middle furrow, which decreased slowly and smoothly from $25 \%$ at the beginning of the experiment to about $10 \%$ in early April. Only from this time onwards, when irrigation was increased, some of the differences in water pattern treatments became discernable at $20 \mathrm{~cm}$ depth (Fig. 3a-c) but fluctuations remained small compared to the top layer. For treatments with shallow groundwater, SWC at $20 \mathrm{~cm}$ depth was generally higher compared with same water pattern under drained conditions. The differences in SWC between the middle and front furrow under APRD and FPRD were also much larger than under drained conditions (Fig. 3d-f) and similar to those in the top soil layer (see Fig. 2). 
Fig. 2 The volumetric soil water content (SWC) of the top soil layer in Experiment 1, from late March until late May, as measured weekly with moisture meter type $\mathrm{HH} 2$. Bars represent Means $\pm \mathrm{SE}$

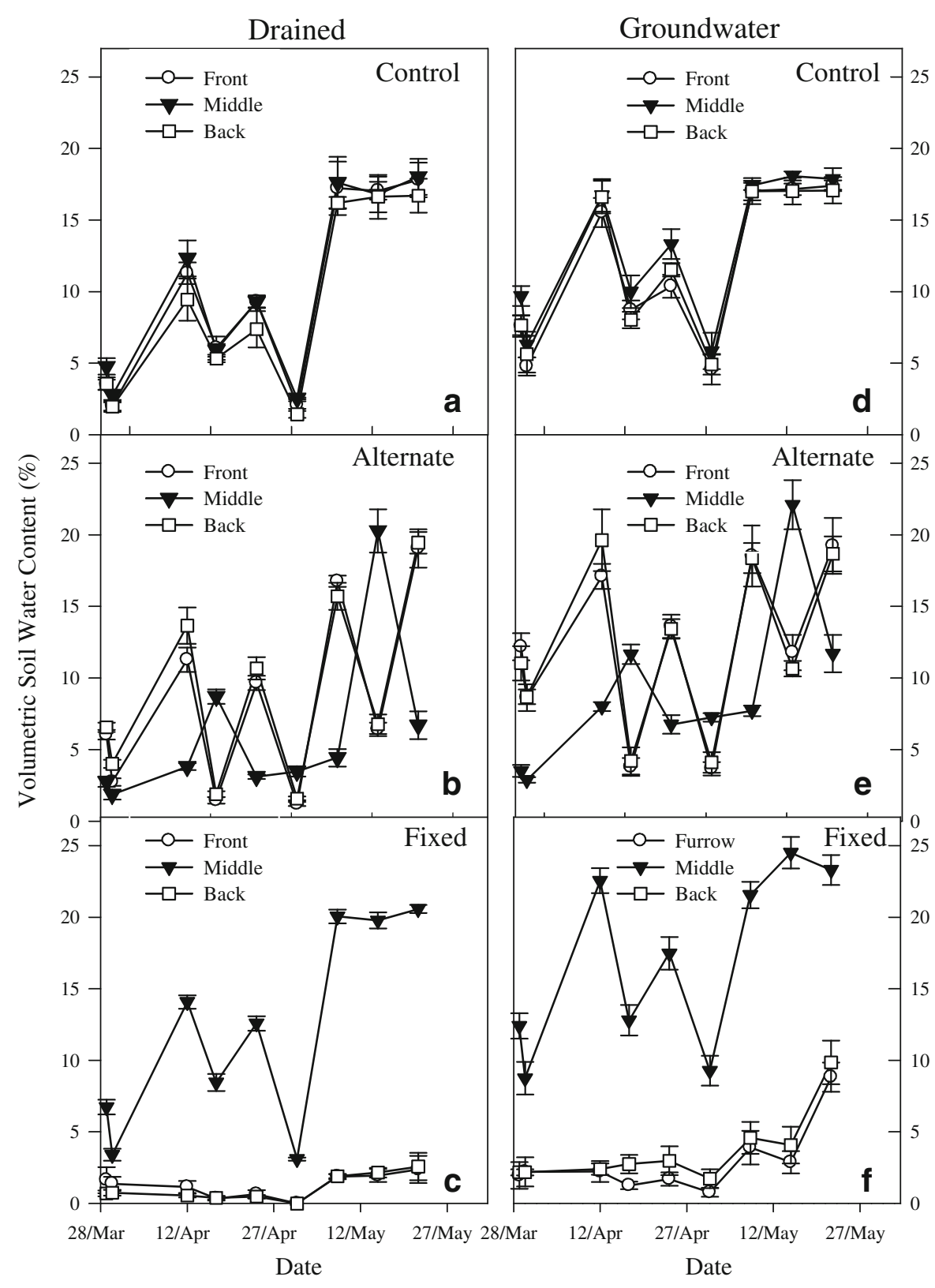

\section{Aboveground morphology, biomass and yield}

Plants in treatments with shallow groundwater were much taller and larger than those under drained conditions (Fig. 4). They had more than twice the branch length, produced more pods and dry biomass, had less aborted flowers but lighter seeds. Seed yield per plant was also higher for the groundwater treatment, especially due to the larger number of pods produced, as the seed weight per pod was similar for all treatments. Fig. 4 also shows that plants watered by different water patterns were similar in terms of morphology and biomass, both in the groundwater and the drained treatments (Table 1). Under drained conditions, plants under Alternate watering (APRD) tended to produce more seed weight per plant than under Control (CI) and Fixed irrigation (FPRD), especially due to a relatively heavy weight per seed, but these results were not significant.

Plants grown with shallow groundwater had significantly larger stem diameter, and more branches and sub-branches with pods, than plants under 


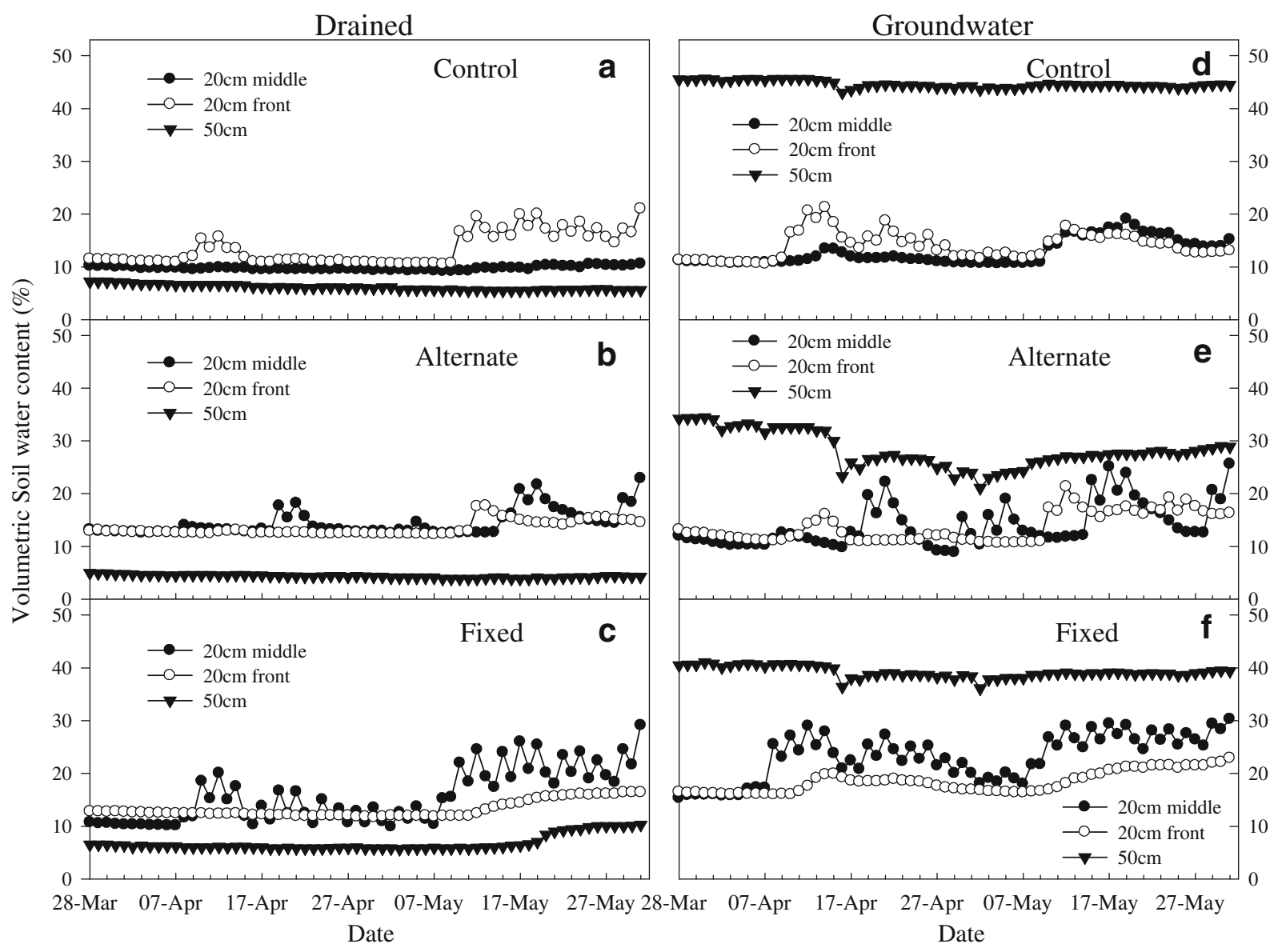

Fig. 3 The volumetric soil water content (SWC) of Experiment 1 at depths of $20 \mathrm{~cm}$ (beneath the middle and front furrow) and $50 \mathrm{~cm}$ (in the middle of the compartment). The SWC was automatically recorded by TDR probes

drained conditions (Table 1). The number of branches on the main stem, however, was always approximately 19 , irrespective of treatment. None of these morphological characteristics varied significantly among the water pattern treatments, although under $\mathrm{CI}$ and APRD plants tended to produce thicker stems and more sub-branches than under FPRD (results not shown).

\section{Root length density}

Plants in the drained treatments produced more roots in the top than in the deeper soil layers (Fig. 5a), in contrast to treatments with shallow groundwater with most of the roots in the bottom or middle layers (Fig. 5b, Table 2-layer model). Under drained conditions, root horizontal distribution (i.e. between furrows) was only affected by Fixed watering (FPRD) with little root development under the dry front and back furrows, while roots were distributed evenly amongst the three furrows of CI and APRD (Fig. 5a; Table 2-furrow model). The root length density in the exclusively watered middle furrow of FPRD was the same as in CI. The root proliferation in the top soil layer under the wet furrow under FPRD was not observed when shallow groundwater was present (Fig. 5b).

\section{Experiment 2}

\section{Soil water content (SWC)}

SWC dynamics were very different for the different treatments. SWC in control $(100 \%$ watering) and CI (50\% watering) varied in a range of $20-30 \%$ and $5-$ $15 \%$, respectively. For APRD, the SWC of the wet and dry parts of the pot fluctuated between $10-20 \%$ and $5-10 \%$, respectively, clearly reflecting the alter- 
Fig. 4 Oilseed rape morphology in response to groundwater presence and watering patterns in Experiment 1. a Plant height and total branch length; b The number of aborted flowers and pods (plump pods with seeds); c Dry biomass aboveground; d 500-seed weight, seed weight per pod and seed number per pod.

Bars represent Means $\pm \mathrm{SE}$. Watering patterns are Conventional irrigation (C), Alternate Partial Root-zone Drying Irrigation (A), Fixed Partial Root-zone Drying Irrigation (F). Groundwater is either present $(\mathbf{G})$ of absent (D, drained)
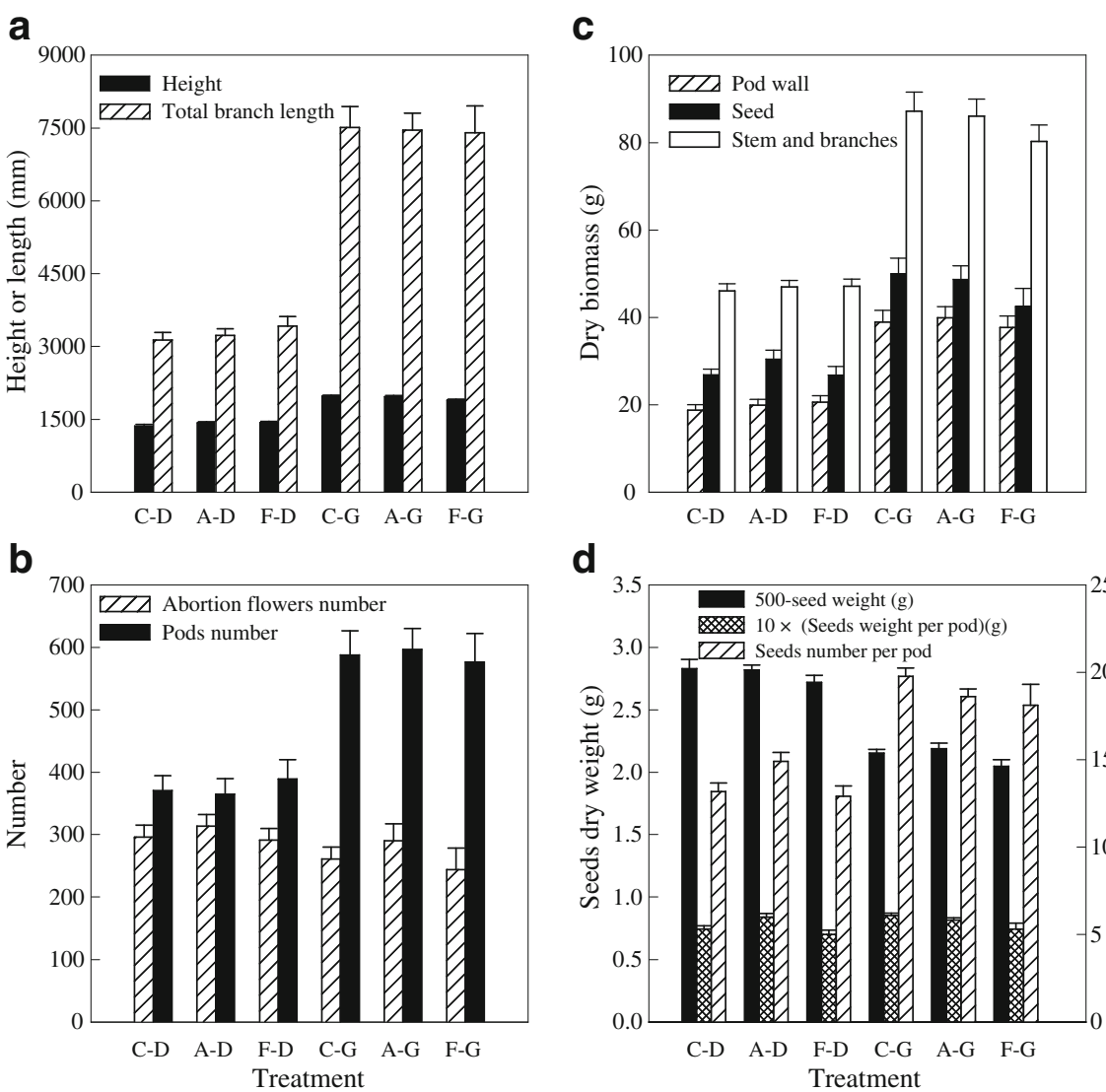

nating watering, with the dry side dropping below 5\% SWC occasionally. In the case of FPRD, SWC of the wet side bounced between $5 \%$ and $20 \%$, and the SWC of the dry side remained steady below $5 \%$.

\section{Aboveground morphology and biomass}

Reducing the water supply with $50 \%$ resulted in markedly shorter plants with less branch length, fewer pods, and less biomass in stems, branches and seeds $(P<0.05$; Fig. 6). However, the number of seeds per pod and the seed weight per pod were independent of water supply, and the individual seed weight tended to be smaller in the $100 \%$ control. Differences in all these characteristics as a result of water patterns were small and not significant (Fig. 6).

\section{Root length density}

Root length densities in the Control (100\% watered) were significantly smaller than in CI which was supplied with only half the amount of water $(P<0.05$; results not shown). As expected roots foraged for water in the wet part of the FPRD pots, resulting in very different root length densities in the two sides of the pot. No such differences were observed in the other treatments.

\section{Discussion}

Soil water content (SWC)

In experiment 1 , only in the top soil (up to about $10 \mathrm{~cm}$ depth), water patterns and dynamics were markedly different between the different water supply patterns, irrespective of groundwater treatment. At slightly greater depth $(20 \mathrm{~cm})$ fluctuations in the alternate watering treatment (APRD) were hardly discernable under drained treatments, probably because the dense layer of roots in the top soil took up the water before it was able to infiltrate. In the presence of groundwater with less water stress to the plants, these fluctuations covered a larger part of the soil column. We conclude 


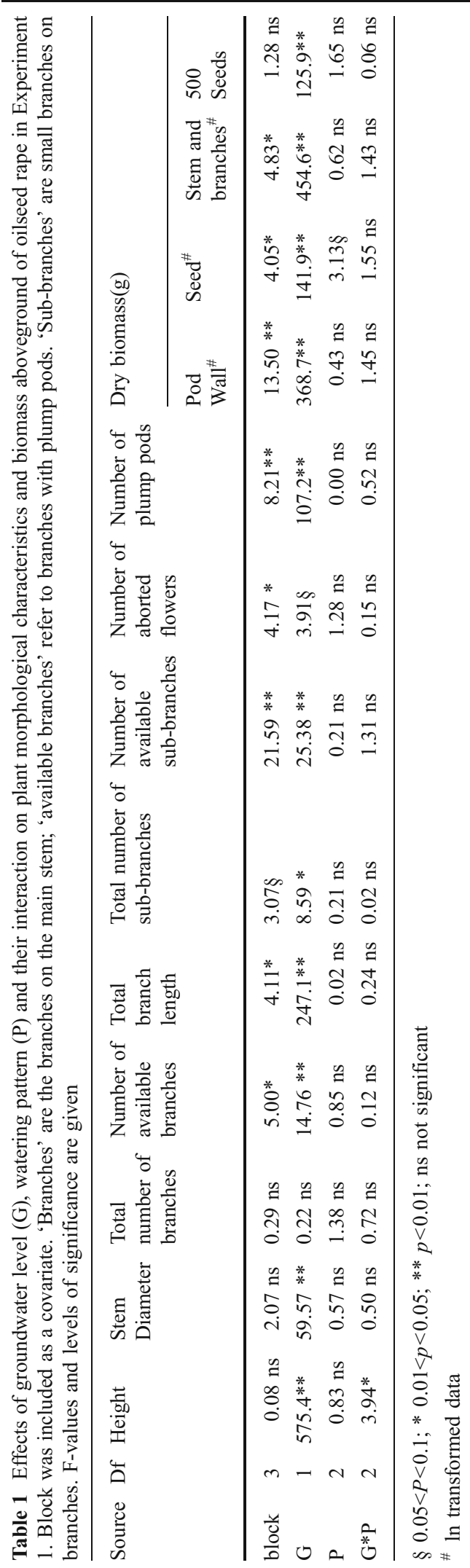

that partial root-zone drying treatments induce expected differences in SWC only in the top soil layer, and that a larger part of the soil column is affected only if the plants grow under less water stress.

Another conspicuous feature from our measurements of SWC in both experiments is that dry roots occasionally develop in all treatments, not only when partial root-zone drying is induced (see also Wang et al. 2007). In our Phytotron plants grew under nearambient conditions, and our water regimes reflected current crop practices under partial root-zone drying. Therefore, also in field crops, a short period of hot summer days increases evaporation and transpiration so that the top soil layer readily dries out, unless irrigation is instantaneously increased. It should thus be realized that due to erratic weather conditions, roots will be exposed to temporary dry conditions under nearly all water regimes, possibly lowering the effectiveness of partial root-zone drying irrigation regimes.

\section{Root length density}

Roots do not encounter belowground resources (mineral nutrients and water) passively, but actively forage for nutrient hotspots and avoid patches where root densities of competing neighbors are high (de Kroon et al. 2003; Hodge 2004). Our results show that the root length density of oilseed rape was extremely plastic in vertical and horizontal distribution, in response to water supply, confirming earlier pot studies with smaller plants (Wang et al. 2005, 2007). Similar to some other crops (Reid et al. 1997; Stone et al. 2001), root plasticity in oilseed rape involves the ability of plants to maintain a shallow root system to use rainfall and irrigation, as well as a deep root system to use available moisture deeper in the soil profile particularly under drought (Duncan et al. 1997; Songsri et al. 2008). Groundwater was indeed exploited very effectively by root proliferation in the deep moist soil layers, which overruled the response of the roots to the wet furrow in the top layer in the Fixed watering treatment (FPRD). The large root plasticity might be the reason why oilseed rape can be grown under a wide variety of soil, water and climatic conditions. This strong adaptability of oilseed rape may help to explain why only slight differences in growth and yield have been found among distinct water pattern treatments. 


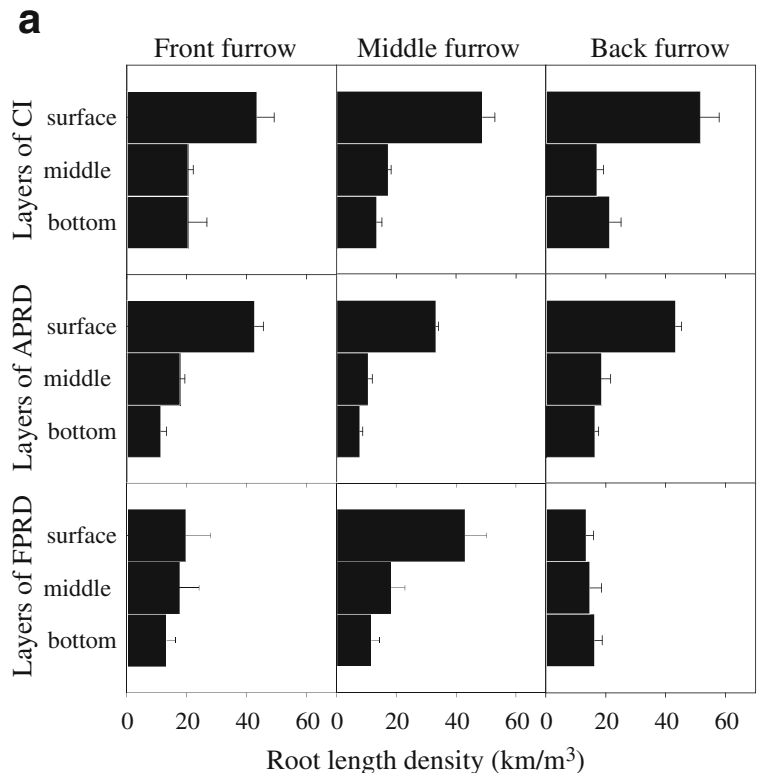

b

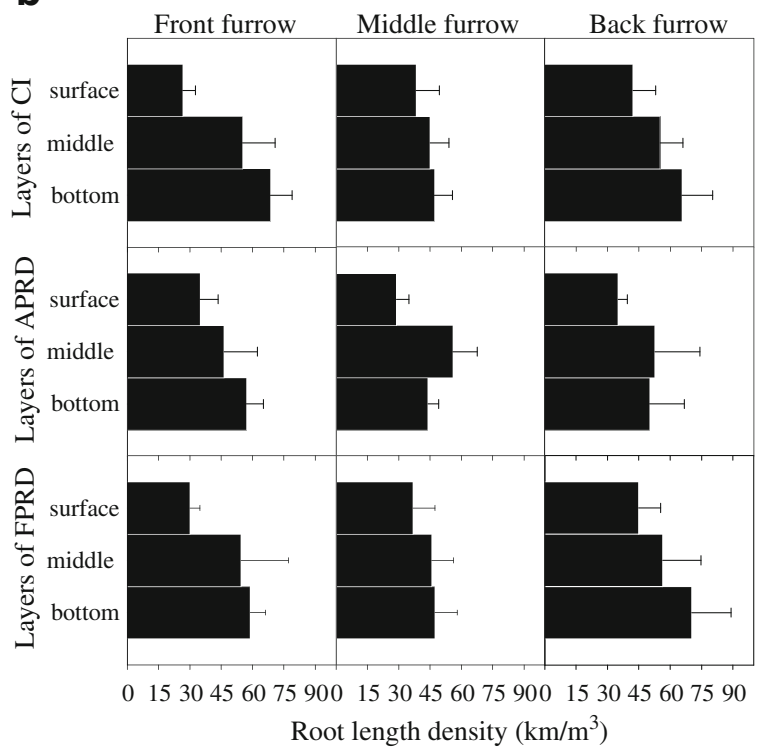

Fig. 5 Root spatial distribution under drained conditions a and in the presence of groundwater presence $\mathbf{b}$ in Experiment 1. Water patterns are CI, Conventional irrigation; APRD, Alternate Partial Root-zone Drying Irrigation; FPRD, Fixed Partial Root-zone Drying Irrigation. Bars represent Means $\pm \mathrm{SE}$

Aboveground morphology, biomass and yield

Water is a key resource in agriculture. Our results indeed show that plants with access to shallow groundwater (Experiment 1) or grown under sufficient watering (Experiment 2) grow more vigorously producing higher seed yield than plants under deficient irrigation. Further analysis of growth and yield components revealed that the higher yield was due to longer branches on the main stem, carrying a larger number of pods (see also Wright et al. 1995; Norouzi et al. 2008). The number of main branches did not vary suggesting that these branches were already formed very early in development and hence were not able to respond to water conditions. Seed weight per pod was equally constant, but enhanced water supply resulted in more seeds each with a lower weight (Wright et al. 1995).

In contrast to expectation, there were hardly any significant differences in terms of morphology and yield as a result of the partial root-zone drying treatments, for which the total supply of water was the same. This lack of effects may be explained by a number of reasons. First, as noted above, roots were extremely effective in finding the discrete water sources supplied. The root foraging ability of oilseed rape may have reduced the necessity to respond to dry root signals. As many crops are likely to have a plastic root system, this may equally apply to other crops in which alternate partial root-zone drying does not lead to higher yields compared to other water deficient treatments (e.g. Wakrim et al. 2005). Moreover, some of the roots in all treatments were episodically exposed to dry soil, which may reduced the effectiveness of the water pattern treatments. Although an earlier experiment with oilseed rape

Table 2 Effects of groundwater level (G), watering pattern (P) and their interaction on root length densities of oilseed rape in Experiment 1. Differences between soil layers (Layer model) and furrows (Furrow model) were analyzed separately as repeated measurement factors (see Methods for further details). Block was included as a covariate. F-values and levels of significance are given

\begin{tabular}{lllll}
\hline DF & \multicolumn{2}{l}{ Layer Model $^{*}$} & \multicolumn{2}{l}{ Furrow Model } \\
\hline 3 & Block & $11.50 * *$ & Block & $13.67 * *$ \\
1 & $\mathrm{G}$ & $88.27 * *$ & $\mathrm{G}$ & $82.34 * *$ \\
2 & $\mathrm{P}$ & $2.02 \mathrm{~ns}$ & $\mathrm{P}$ & $3.52 \S$ \\
2 & $\mathrm{G} * \mathrm{P}$ & $1.15 \mathrm{~ns}$ & $\mathrm{G} * \mathrm{P}$ & $2.78 \S$ \\
2 & $\mathrm{~L}$ & $9.24 * *$ & $\mathrm{~F}$ & $1.21 \mathrm{~ns}$ \\
6 & $\mathrm{~L} * \mathrm{~B}$ & $2.02 \S$ & $\mathrm{F} * \mathrm{~B}$ & $1.13 \mathrm{~ns}$ \\
2 & $\mathrm{~L} * \mathrm{G}$ & $63.93 * *$ & $\mathrm{~F}^{*} \mathrm{G}$ & $0.47 \mathrm{~ns}$ \\
4 & $\mathrm{~L} * \mathrm{P}$ & $1.59 \mathrm{~ns}$ & $\mathrm{~F}^{*} \mathrm{P}$ & $1.96 \mathrm{~ns}$ \\
4 & $\mathrm{~L} * \mathrm{G} * \mathrm{P}$ & $2.39 \S$ & $\mathrm{F}^{*} \mathrm{G} * \mathrm{P}$ & $3.50 *$ \\
\hline
\end{tabular}

$\S 0.05<P<0.1 ; * 0.01<p<0.05 ; * * p<0.01 ;$ ns not significant

\# $\ln$ transformed data 
Fig. 6 Oilseed rape morphology in response to water amount and water patterns in Experiment 2. a Height and total branch length; b The number of aborted flowers and pods (plump pods with seeds); c Dry biomass aboveground; d 500-seed weight, seed weight per pod and seed number per pod. Bars represent Means $\pm \mathrm{SE}$. Control is $100 \%$ water supply; watering patterns (each with $50 \%$ water supply) are Conventional irrigation $(\mathbf{C})$, Alternate Partial Root-zone Drying Irrigation (A), Fixed Partial Root-zone Drying Irrigation (F)

\section{a}

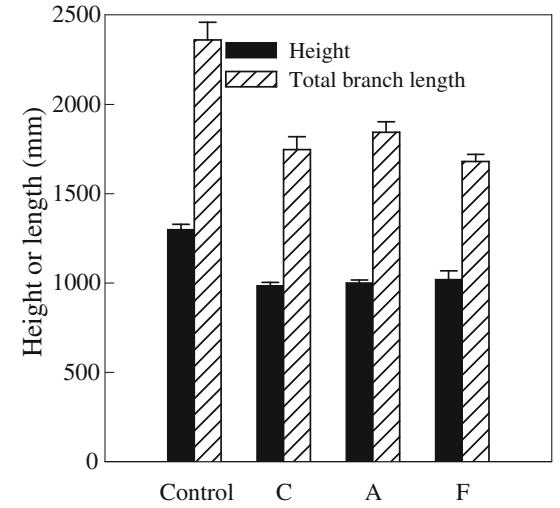

b

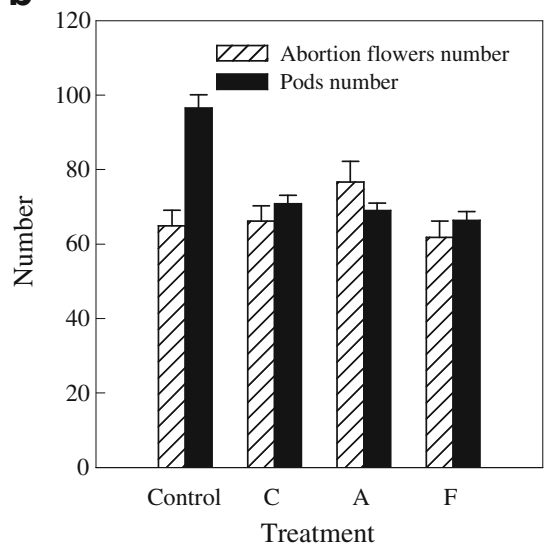

C

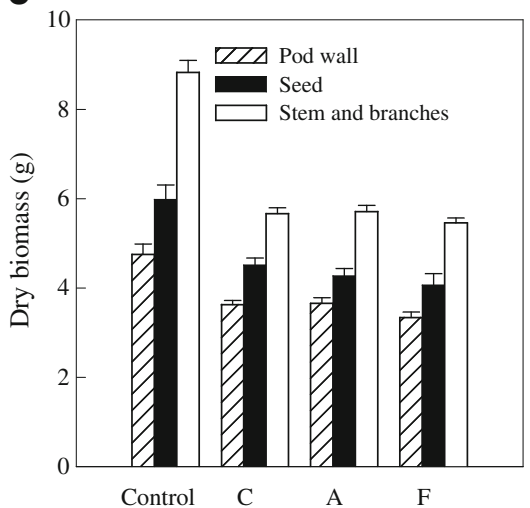

d

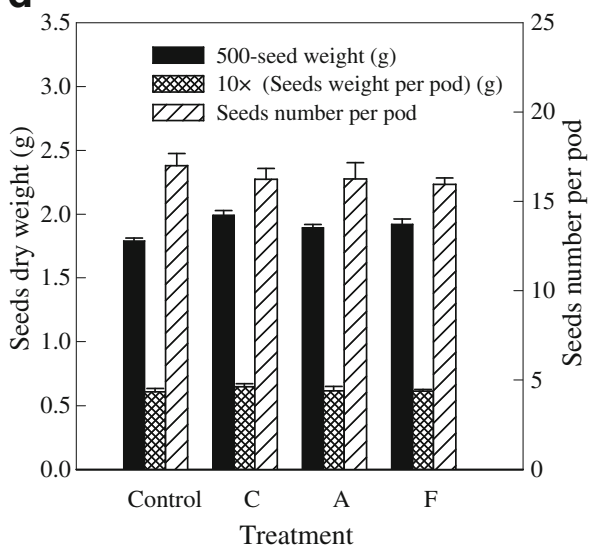

showed that stomatal conductance was significantly more reduced under alternate drying (APRD) than under control and fixed water regimes (CI and FPRD; Wang et al. 2005), these relatively small differences may not have been sufficient to elicit different growth and yield responses aboveground (cf. Dembinska et al. 1992; Liu et al. 2004).

Another reason for the low effectiveness of the water pattern treatments may be that even if APRD affects water use efficiency of leaves in the early stage of growth, it may not do so in the fruiting stage because pod filling depends on photosynthesis of the pod wall. In Brassica, photosynthesis by chloroplasts in the outer pod wall layer is the major source of assimilates for seed growth (70-100\%; Sheoran et al. 1991), and the stomata density in stems and pods is only half of that in leaves and bracts (Jensen et al. 1996). Due to their low stomatal conductance and succulent character, the pods of oilseed rape are able to both reduce water loss and to act as a buffer of the tissue water content, so that less severe water deficits occurs in the pods (Mogensen et al. 1997). Alternate watering patterns may thus not have improved the pod wall photosynthesis or pod water status of oilseed rape because of low stomata density.

Finally, the results may have been affected by the indeterminate growth habit of oilseed rape, in combination with the very early onset of the season in the year of our experiment. Indeterminate growth habit means that vegetative and reproductive growth take place at the same time. In contrast, plants with determinate growth habit stop vegetative growth when they become mature and start to reproduce (Adhikari et al. 2002; Uzun et al. 2005). In oilseed rape, following winter dormancy, new leaves emerge and the rapeseed plant develops a single stalk from the crown, with most of the seed pods developing on the branches. Plants with indeterminate growth habit are known to be very flexible in their responses of growth and yield to water stress and different environmental conditions (De Costa et al. 1997; Black et al. 2000; Boutraa and Sanders 2001). This is consistent with the response of oilseed rape in our experiments, where the formation of longer branches 
and more sub-branches resulted in more pods when water stress was alleviated. It seems that, if APRD indeed increases the water use efficiency of the leaves, this process may not immediately result in the formation of more pods, in a species with indeterminate growth. Moreover, our conditions were such that the watering patterns had only a reduced period to affect the physiology of the plants, prior to flowering. Experiment 1 was conducted in the warmest winter in the Netherlands in 300 years in 2006 and a very warm early spring in 2007 (source: www.knmi.nl). The plants kept growing even in winter and bolted early (late February) shortly after the start of water patterns (mid-January). Although, in Experiment 2, water pattern treatments were in effect from the beginning, early flowering occurred also here shortly after vernalization. Friend (1985) pointed that yield of oilseed rape can be increased by prolonging the vegetative stage and thus increasing the size of the inflorescence, but our experimental conditions precluded the water patterns to have an effect in this stage of plant development.

\section{Conclusion}

In our experimental conditions, oilseed rape responded vigorously to improved water status as a result of groundwater, but not to water patterns associated with partial root-zone drying, in contrast to some results of previous studies on other crops. Our detailed measurements of soil water content and root distribution suggest that root foraging responses and intermittent droughts in all treatments may have overwhelmed any possible effects of partial drying of the roots and their associated effects of leaf physiology. Moreover, in crops with indeterminate growth with a short vegetative growth phase, partial root-zone drying may be ineffective in enhancing the major yield components. Our study was unable to decipher exactly what caused the small differences among the different water pattern treatments, and more studies are needed on water stress physiology under partial root-zone drying, especially in the fruiting stage of crops with different growth habits.

Acknowledgements We thank Yvette Evers, Harry van Zuylen and Walter Hendrickx for their assistance in the experimental garden. Statistical analysis suggestions from Josef F. Stuefer are greatly indebted. We thank Xin Chen for helping collecting data, and Linde Hess for comments and suggestions. Financial support from a DELTA grant from the Dutch Ministry of Education, National Basic Research Priorities Program of China (2006CB403406) and National 863 High Technology Research Plan Project of China (2006AA100203) are greatly acknowledged.

Open Access This article is distributed under the terms of the Creative Commons Attribution Noncommercial License which permits any noncommercial use, distribution, and reproduction in any medium, provided the original author(s) and source are credited.

\section{References}

Adhikari KN, Galwey NW, Dracup M (2002) The genetic control of mildly restricted branching in narrow-leafed lupin (Lupinus angustifolius L.). Euphytica 123:101-109 doi:10.1023/A:1014420902282

Al-Jaloud AA, Hussian G, Karimulla S, Al-Hamidi AH (1996) Effect of irrigation and nitrogen on yield and yield components of two rapeseed cultivars. Agric Water Manage 30:57-68 doi:10.1016/0378-3774(95)01207-9

Black VJ, Black CR, Roberts JA, Stewart CA (2000) Impact of ozone on the reproductive development of plants. New Phytol 147:421-447 doi:10.1046/j.1469-8137.2000.00721.x

Black VJ, Stewart CA, Roberts JA, Black CR (2007) Ozone affects gas exchange, growth and reproductive development in Brassica campestris (Wisconsin Fast Plants). New Phytol 176:150-163 doi:10.1111/j.1469-8137.2007.02163.x

Boutraa T, Sanders FE (2001) Influence of water stress on grain yield and vegetative growth of two cultivars of bean (Phaseolus vulgaris L.). J Agron Crop Sci 187:251-257 doi:10.1046/j.1439-037X.2001.00525.X

Buttar GS, Thind HS, Aujla MS (2006) Methods of planting and irrigation at various levels of nitrogen affect the seed yield and water use efficiency in transplanted oilseed rape (Brassica napus L.). Agric Water Manage 85:253-260 doi:10.1016/j.agwat.2006.05.008

Centritto M, Wahbi S, Serraj R, Chaves MM (2005) Effects of partial rootzone drying (PRD) on adult olive tree (Olea europaea) in field conditions under arid climate II. Photosynthetic responses. Agric Ecosyst Environ 106:303-311 doi:10.1016/j.agee.2004.10.016

Cifre J, Bota J, Escalona JM, Medrano H, Flexas J (2005) Physiological tools for irrigation scheduling in grapevine (Vitis vinifera L.) An open gate to improve water-use efficiency? Agric Ecosyst Environ 106:159-170 doi:10.1016/j.agee.2004.10.005

De Costa WAJM, Dennett MD, Ratnaweera U, Nyalemegbe K (1997) Effects of different water regimes on field-grown determinate and indeterminate faba bean (Vicia faba L.). II. Yield, yield components and harvest index. Field Crops Res 52:169-178 doi:10.1016/S0378-4290(96)01060-X

Davies WJ, Bacon MA, Thompson DS, Sobeih W, Rodriguez LG (2000) Regulation of leaf and fruit growth in plants growing in drying soil: exploitation of the plants' chemical signalling system and hydraulic architecture to increase 
the efficiency of water use in agriculture. J Exp Bot 51:1617-1626 doi:10.1093/jexbot/51.350.1617

de Kroon H, Mommer L Nishiwaki A (2003) Root competition: towards a mechanistic understanding. In: de Kroon H, Visser JWE (eds) Root ecology. Springer, Berlin, pp 215-231

Dembinska O, Lalonde S, Saini HS (1992) Evidence against the regulation of grain set by spikelet abscisic acid levels in water-stressed wheat. Plant Physiol 100:1599-1602 doi:10.1104/pp.100.3.1599

Duncan RR, Carrow RN (1997) Stress resistant turf-type tall fescue (Festuca arundinacea Schreb.): Developing multiple abiotic stress tolerance. Int Turf Soc Res J 8:653-662

Friend DJC (1985) Brassica. In: Halevy AH (ed) CRC Handbook of Flowering Plants, 1st edn. CRC Press, Boca Raton, pp 48-77

Hodge A (2004) The plastic plant: root responses to heterogeneous supplies of nutrients. New Phytol 162:9-24 doi:10.1111/j.1469-8137.2004.01015.x

Jensen CR, Mogensen VO, Mortensen G, Fieldsend JK, Milford GFJ, Andersen MN, Thage JH (1996) Seed glucosinolate, oil and protein contents of field-grown rape (Brassica napus L.) affected by soil drying and evaporative demand. Field Crops Res 47:93-105 doi:10.1016/ 0378-4290(96)00026-3

Kang S, Liang Z, Pan Y, Shi P, Zhang J (2000) Alternate furrow irrigation for maize production in an arid area. Agric Water Manage 45:267-274 doi:10.1016/S0378-3774(00)00072-X

Kang S, Shi W, Cao H, Zhang J (2002) Alternate watering in soil vertical profile improved water use efficiency of maize (Zea mays). Field Crops Res 77:31-41 doi:10.1016/ S0378-4290(02)00047-3

Kang S, Zhang J (2004) Controlled alternate partial root-zone irrigation: its physiological consequences and impact on water use efficiency. J Exp Bot 55:2437-2446 doi:10.1093/jxb/erh249

Kang S, Zhang L, Hu X, Li Z, Jerie P (2001) An improved water use efficiency for hot pepper grown under controlled alternate drip irrigation on partial roots. Sci Hortic (Amsterdam) 89:257-267 doi:10.1016/S0304-4238(00)00245-4

Kirda C, Cetin M, Dasgan Y, Topcu S, Kaman H, Ekici B, Derici MR, Ozguven AI (2004) Yield response of greenhouse grown tomato to partial root drying and conventional deficit irrigation. Agric Water Manage 69:191-201 doi:10.1016/j.agwat.2004.04.008

Leib BG, Caspari HW, Redulla CA, Andrews PK, Jabro JJ (2006) Partial rootzone drying and deficit irrigation of 'Fuji' apples in a semi-arid climate. Irrig Sci 24:85-99 doi:10.1007/s00271-005-0013-9

Liu F, Shahnazari A, Andersen MN, Jacobsen S, Jensen CR (2006) Physiological responses of potato (Solanum tuberosum L.) to partial root-zone drying: ABA signalling, leaf gas exchange, and water use efficiency. $\mathrm{J}$ Exp Bot 57:3727-3735 doi:10.1093/jxb/erl131

Liu FL, Jensen CR, Andersen MN (2004) Pod set related to photosynthetic rate and endogenous ABA in soybeans subjected to different water regimes and exogenous ABA and BA at early reproductive stages. Ann Bot (Lond) 94:405-411 doi:10.1093/aob/mch157

Maisiri N, Senzanje A, Rockstrom J, Twomlow SJ (2005) On farm evaluation of the effect of low cost drip irrigation on water and crop productivity compared to conventional surface irrigation system. Phys Chem Earth 30:783-791

Mandal KG, Hati KM, Misra AK, Bandyopadhyay KK (2006) Assessment of irrigation and nutrient effects on growth, yield and water use efficiency of Indian mustard (Brassica juncea) in central India. Agric Water Manage 85:279-286 doi:10.1016/j.agwat.2006.05.004

Mogensen VO, Jensen CR, Mortensen G, Andersen MN, Schjoerring JK, Thage JH, Koribidis J (1997) Pod photosynthesis and drought adaptation of field grown rape (Brassica napus L.). Eur J Agron 6:295-307 doi:10.1016/S1161-0301 (96)02052-7

Norouzi M, Toorchi M, Salekdeh GH, Mohammadi SA, Neyshabouri MR, Aharizad S (2008) Effect of water deficit on growth, grain yield and osmotic adjustment in rapeseed. J Food Agric Environ 6:312-318

Panda RK, Behera SK, Kashyap PS (2003) Effective management of irrigation water for wheat under stressed conditions. Agric Water Manage 63:37-56 doi:10.1016/ S0378-3774(03)00099-4

Rathke G-W, Diepenbrock W (2006) Energy balance of winter oilseed rape (Brassica napus L.) cropping as related to nitrogen supply and preceding crop. Eur J Agron 24:3544 doi:10.1016/j.eja.2005.04.003

Reid JB, Renquist AR (1997) Enhanced root production as a feed-forward response to soil water deficit in field-grown tomatoes. Aust J Plant Physiol 24:685-692

Sepaskhah AR, Karngar-Haghighi AA (1997) Water use and yields of sugarbeet grown under every-other-furrow irrigation with different irrigation intervals. Agric Water Manage 34:71-79 doi:10.1016/S0378-3774(96)01290-5

Sheoran IS, Sawhney V, Babbar S, Singh R (1991) In vivo fixation of $\mathrm{CO}_{2}$ by attached pods of Brassica campestris L. Ann Bot (Lond) 67:425-428

Songsri P, Jogloy S, Vorasoot N, Akkasaeng C, Patanothai A, Holbrook CC (2008) Root distribution of drought-resistant peanut genotypes in response to drought. J Agron Crop Sci 194:92-103 doi:10.1111/j.1439-037X.2008.00296.x

Stone LR, Goodrum DE, Jaafar MN, Khan AH (2001) Rooting front and water depletion depths in grain sorghum and sunflower. Agron J 93:1105-1110

Sun C, Zhao H, Fang G, Wang W, Li Y, Qian X (2002) Breeding of a double low rapeseed variety Huyou No. 15 in Brassica napus L. Chinese journal of oil crop sciences 24(3):65-67 (in Chinese)

Uzun A, Bilgili U, Sincik M, Filya I, Acikgoz E (2005) Yield and quality of forage type pea lines of contrasting leaf types. Eur J Agron 22:85-94 doi:10.1016/j.eja.2004.01.001

Wakrim R, Wahbi S, Tahi H, Aganchich B, Serraj R (2005) Comparative effects of partial root drying (PRD) and regulated deficit irrigation (RDI) on water relations and water use efficiency in common bean (Phaseolus vulgaris L.). Agric Ecosyst Environ 106:275-287 doi:10.1016/j. agee.2004.10.019

Wang L, de Kroon H, Bögemann GM, Smits AJM (2005) Partial root drying effects on biomass production in Brassica napus and the significance of root responses. Plant Soil 276:313-326 doi:10.1007/s11104-005-5085-Z

Wang L, de Kroon H, Smits AJM (2007) Combined effects of partial root drying and patchy fertilizer placement on 
nutrient acquisition and growth of oilseed rape. Plant Soil 295:207-216 doi:10.1007/s11104-007-9276-7

Wright PR, Morgan JM, Jessop RS, Cass A (1995) Comparative adaptation of canola (Brassica napus) and Indian mustard (B. juncea) to soil water deficits: yield and yield components. Field Crops Res 42:1-13 doi:10.1016/03784290(95)00013-G

Zegbe-Domínguez JA, Behboudian MH, Lang A, Clothier BE (2003) Deficit irrigation and partial rootzone drying maintain fruit dry mass and enhance fruit quality in
'Petopride' processing tomato (Lycopersicon esculentum Mill.). Sci Hortic (Amsterdam) 98:505-510 doi:10.1016/ S0304-4238(03)00036-0

Zhang H, Turner NC, Poole ML (2004) Yield of wheat and canola in the high rainfall zone of south-western Australia in years with and without a transient perched watertable. Aust J Agric Res 55:461-470 doi:10.1071/AR03122

Zhang L, Yu Y (2003) A new rapeseed variety-Huyou No. 15 in Brassica napus L. Shanghai agricultural science and technology 1:3 (in Chinese) 